\title{
MEDIA VIDEO PEMBELAJARAN DALAM MENINGKATKAN MOTIVASI DAN PRESTASI MAHASISWA
}

\author{
Cut dhien nurwahidah \\ cut.dhien@uinjkt.ac.id \\ (Fakultas Ilmu Tarbiyah dan Keguruan (FITK) Universitas Islam Negeri \\ Syarif Hidayatullah, Jakarta) \\ Zaharah \\ zaharah@uinjkt.ac.id \\ (Fakultas Ilmu Tarbiyah dan Keguruan (FITK) Universitas Islam Negeri \\ Syarif Hidayatullah, Jakarta) \\ Ibnu Sina \\ Ibnu-sina19@gmail.com \\ (Universitas Pamulang, Tangerang Selatan)
}

\begin{abstract}
Abstrak
Tujuan penelitian ini adalah untuk mengetahui tentang penggunaan Video sebagai media pembelajaran dalam upaya meningkatkan motivasi dan prestasi belajar mahasiswa pada fakultas Ilmu Tarbiyah dan keguruan Universitas Islam Negeri Syarif Hidayatullah, Jakarta. Penelitian ini dilakukan pada mahasiswa Fakultas Ilmu Tarbiyah Program Studi Ilmu Pengetahuan Sosial (IPS). Metode penelitian menggunakan pendekatan kuantitatif diskriptif Sedangkan untuk telaah pustaka penulis melakukan sebagai dasar argumentasi baik melalui hasil penelitian sebelumnya di jurnal penelitian, buku yang terkait maupun kajian kritis teoritis. Subjek penelitian ini adalah mahasiswa Prodi IPS tahun ketiga yang berjumlah 40 orang, sumber data digunakan dengan menyebarkan angket dan wawancara secara virtual. Hasil penelitian menunjukkan bahwa penggunaan video sebagai alat bantu mengajar memberikan satu pengalaman baru kepada peserta didik.Analisis diskriptiv menunjukan rata - rata mahasiswa suka menggunaan video dalam pembelajaran sebesar $54.55 \%$ dengan standar deviasi 4.01, dan motivasi mahasiswa dalam mengikuti perkuliahan media pembelajaran IPS sebesar 56,27 \% standar deviasi 3.78 dan prestasi mahasiswa dalam mengikuti perkuliahan dengan mengunakan media video pembelajaran IPS sebesar $51,82 \%$ denga standar deviasi 3,054.ini menunjukan bahwa memang motivasi belajar mahasiswa dengan menggunaan media pembelajaran sangat signifikan. Dengan penayangan Video pembelajaran, mahasiswa dapat merasa seolah-olah mereka berada atau turut serta dalam suasana yang digambarkan. Dari hasil penelitian ini juga diketahui bahwa pengunaan media Video pembelajaran akan lebih cepat paham dan mengerti dan motivasi belajar dan prestasi belajar akan meningkat didalam proses pembelajaran .Oleh karena itu, para guru atau dosen sebaiknya memfungsikan media vedio pembelajaran dengan baik dan perlu dimanfaatkan secara sinergis untuk mengoptimalkan pembelajaran, Sehingga dapat menciptakan kondisi yang dapat mendorong siswa agar dapat mencapai kompetensi dalam pembelajaran yang diberikan oleh pengajar. Adanya media video pembelajaran peserta didik mampu mencapai kemampuan dalam ranah kognitif, afektif, psikomotorik dan dapat meningkatkan kemampuan interpersonal.
\end{abstract}

Katakunci : Media Pembelajaran, Video, Motivasi, prestasi belajar. 


\begin{abstract}
The purpose of this study was to find out about the use of video as a learning medium in an effort to increase student motivation and achievement at the Faculty of Tarbiyah Science and teacher training at Syarif Hidayatullah State Islamic University, Jakarta. This research was conducted on students of program Social Sciences (IPS). The research method uses a descriptive quantitative approach. Meanwhile, for the literature review, the writer does this as a basic for argumentation either through previous research results in research journals, related books or theoretical critical studies. The subjects of this study were 40 third-year students of the Social Studies Program, the data source used by distributing questionnaires and interviews virtually. The results showed that the use of video as a teaching aid provided a new experience for students. Descriptive analysis showed that the average student like to use video in learning was $54.55 \%$ with a standard deviation of 4.01 , and student motivation in taking social studies learning media was 56. 27\% standard deviation is 3.78 and student achievement in attending lectures using social studies learning video media is $51.82 \%$ with a standard deviation of 3.054. This shows that indeed student learning motivation using learning media is very significant. By viewing the instructional videos, students can feel as if they are participating in the atmosphere described. From the results of this study it is also known that the use of video learning media and understand faster and learning motivation and learning achievement will increase in the learning process. Therefore, teachers or lecturers should function the learning media properly and need to be used synergistically to optimize learning, the create conditions that can encourage students to achieve competence in the learning given by the teacher. The existence of video learning media, students are able to achieve abilities in the cognitive, affective, psychomotor domains and can improve interpersonal skills.
\end{abstract}

\title{
Keyword: Learning Media, Videos, Motivation, Learning Achievement
}

\section{A. Pendahuluan}

Video merupakan media elektronik yang mampu menggabungkan teknologi audio dan visual secara bersama sehingga menghasilkan suatu tayangan yang dinamis dan menarik (Arif Yudianto 2017) ${ }^{1}$. Video dapat dibuat dalam bentuk VCD, DVD dan media internet seperti youtube, sehingga mudah dibawa dan digunakan dimanapun, selain itu juga mudah digunakan, dan dapat diakses audiens secara luas. Media video memiliki fungsi sebagai media pembelajaran yaitu fungsi atensi, fungsi afektif, fungsi kognitif dan fungsi kompensatoris (Arsyad 2003) ${ }^{2}$.

\footnotetext{
1 Arif Yudianto Penerapan Video seagai media pembelajaran.ISBN.978-602-50088-0-1.P.

${ }^{2}$ Arsyad, A. (2013). Media Pembelajaran. Jakarta: Rajawali Press.P.
}

Menurut Elihami,dkk $(2018)^{3}$ bahwa "media video adalah media yang menyajikan informasi dalam bentuk suara dan visual". Penggunaan video yang melibatkan indra paling banyak dibandingkan dengan alat peraga lainnya, dengan penayangan video murid dapat melihat sekaligus mendengar. Pemerolehan hasil belajar melalui indera pandang berkisar $75 \%$, melalui indera dengar $13 \%$, dan melalui indera lainnya sekitar $12 \%$ (Rina Cahyani,dkk 2016) ${ }^{4}$. Penggunaan

\footnotetext{
${ }^{3}$ Elihami, E., \& Saharuddin, A. (2017). Peran Teknologi Pembelajaran Islam dalam organisasi Belajar. Edumaspul-Jurnal Pendidikan, 1.P. 1-8.

4 Rina Cahyani , Sarwono, Puguh Karyanto, Penggunaan Media Video untuk Meningkatkan Motivasi dan Hasil Belajar Materi Biosfer pada Siswa Kelas XI IPS MAN 2 Pontianak
} 
audiovisual (video) dinilai sangatlah efektif. Apabila video yang ditayangkan tersebut dilengkapi dengan sebuah software interaktif, maka kemungkinan siswa akan melakukan interaksi dengan program yang ada penggunaan media pembelajaran audiovisual berupa video tersebut akan memberikan motivasi terhadap siswa untuk lebih tertarik terhadap pelajaran yang akan disampaikan, sehinga penggunaan video yang diberikan dalam pembelajaran akan menimbulkan kegairahan dalam diri siswa selama penggunaannya tepat dan sesuai dengan sub bahasan yang disajikan. Memilih media video sebagai media untuk penyebarluasan hasil gagasan sebuah inovasi selain dapat mengkombinasikan visual dengan audio juga dapat dikemas dengan berbagai bentuk, misalkan menggabungkan antara komunikasi tatap muka dengan komunikasi kelompok, menggunakan teks, audio dan musik. Menurut Sudjana dan Rivai (1992) manfaat media video yaitu: (1) dapat menumbuhkan motivasi; (2) makna pesan akan menjadi lebih jelas sehingga dapat dipahami oleh peserta didik dan memungkinkan terjadinya penguasaan dan pencapaian tujuan penyampaian.

Fungsi atensi yaitu media video dapat menarik perhatian dan mengarahkan konsentrasi audiens pada materi video. Fungsi afektif yaitu media video mampu menggugah emosi dan sikap audiens. Fungsi kognitif dapat mempercepat pencapaian tujuan pembelajaran untuk memahami dan mengingat pesan atau informasi yang terkandung dalam gambar atau lambang. Sedangkan fungsi kompensatoris adalah memberikan konteks

Tahun Pelajaran 2015/2016, Jurnal GeoEco ISSN: 2460-0768 Vol. 2, No.2 (Juli 2016) Hal. 198-207

5 Sudjana, N \& Rivai, A. 1992. Media Pembelajaran. Bandung: Penerbit CV. Sinar Baru Bandung. P. kepada audiens yang kemampuannya lemah dalam mengorgani- sasikan dan mengingat kembali informasi yang telah diperoleh. Dengan demikian media video dapat membantu audiens yaitu mahasiswa yang lemah dan lambat menangkap suatu pesan menjadi mudah dalam menerima dan memahami inovasi yang disampaikan, hal ini disebabkan karena video mampu mengkombinasikan antara visual (gambar) dengan audio (suara). Video pembelajaran yang ditujukan untuk mempermudah mahasiswa dalam proses pemahaman materi pelajaran tidak selalu sesuai dengan kebutuhan dan keinginan mahasiswa. Dalam beberapa sistem, video pembelajaran hanya digunakan sebagai bahan pelengkap materi handout, tidak dipersiapkan secara profesional untuk mempresentasikan materi secara menyeluruh (Hauff dan Laaser, 1996) ${ }^{6}$ Motivasi belajar mahasiswa adalah keseluruhan daya penggerak di dalam diri mahasiswa yang menimbulkan kegiatan belajar, yang menjamin kelangsungan dari kegiatan belajar dan yang memberikan arah pada kegiatan belajar, sehingga tujuan yang dikehendaki oleh subjek pelajar itu dapat tercapai. Peserta didik yang memiliki motivasi kuat akan mempunyai banyak energi dalam kegiatan belajar. Hasil belajar adalah segala sesuatu yang diperoleh siswa dalam pengalaman atau latihan yang diikutinya, selama pembelajaran yang berupa keterampilan kognitif, afektif, dan psikomotor, Slameto (2003) ${ }^{7}$.

Dari beberapa difinisi di atas peran media video sangat penting dalam

\footnotetext{
${ }^{6}$ Hauff, Mechthild \& Laaser, Wolfram . 1996. Educational Video and TV in Distance Education - Production and Design Aspects. (Journal of Universal Computer Science,vol.2, no.6(1996),P. 456-473).

7 Slameto. 2003. Belajar dan Faktor Faktor yang Mempengaruhinya . Jakarta : Rineka Cipta.p
} 
kehidupan sehari-hari, karena dapat memberikan informasi yang lebih canggih dan cepat. Video selain memberikan informasi dan hiburan juga dapat dijadikan sebagai media pembelajaran. Tujuannya adalah agar proses pembelajaran lebih cepat ditangkap dan dipahami oleh peserta didik. Selain itu juga para pengajar atau guru lebih mudah menyampaikan materi melalui media video. Tentunya hal tersebut harus didukung oleh ilmu pengetauan dan pengusaan teknologi terhadap materi yang diajarkan.

\section{B. Metode Penelitian}

Penelitian ini menggunakan pendekatan diskriptif kuantitatif yaitu penelitian yang menggunakan strategi menjelaskan dan mengungkapkan makna berdasarkan data interpretatif dan analisis kritis terhadap konten dan kategori yang teridentifikasi. Tinjauan pustaka dilakukan sebagai dasar argumentasi baik melalui hasil penelitian sebelumnya di jurnal penelitian, buku terkait maupun kajian kritis teoritis.Tempat penelitian ini dilaksanakan di Universitas Syarifhidayatullah Jakarta, Fakultas Tarbiyah, Program Studi Ilmu Sosial dengan subjek penelitian adalah mahasiswa , tahun ketiga periode 20202021.

Populasi dalam penelitian ini adalah seluruh mahasiswa IPS pada semester genap, Program Studi Ilmu Sosial (PSIS) dan pengambilan sampel dilakukan secara random sampling, penyebaran koesioner dilakukan melalui google form kepada 40 responden berbentuk questioner dengan 45 iteam dari tiga indikator, yaitu, Penggunaan Video pembelajaran, Motivasi belajar dan prestasi belajar mahasiswa, dengan mengunakan instrument penelitian Skala Likert dalam bentuk check list dengan scor 5-1 dengan menggunakan tahapan analisis diskriptif dan menggunakan peringkat sebagai hasilnya.

Penulis menggunakan metode kuantitatif karena pertimbangan penelitian kuantitatif yang dilakukan penulis untuk mencari fakta dan interpretasi yang tepat, dan analisis Penelitian deskriptif yang dilakukan untuk menggambarkan suatu objek dan subjek yang sedang diteliti tanpa adanya rekayasa. Termasuk mengenai hubungan tentang kegiatan, pandangan, sikap dan proses-proses yang berpengaruh dalam suatu fenomena yang data di analisis menggunakan uji validitas,dan uji reliabilitas, , serta uji Normalitas, dan homogenitas.

\section{Hasil}

Berdasarkan hasil angket yang dibagikan kepada 40 responden dengan masing-masing 15 pertanyaan pada setiap indikator .Ada tiga indikator yang dijadikan aspek penilaian, yaitu 1 . Pemahaman dan penggunaan media pembelajaran (Video) .2. Motivasi belajar siswa dan ke 3. Prestasi belajar siswa. Adapun dari tiga indikator ini untuk memahami tentang media vedio pembelajaran dan motivasi belajar siswa serta prestasi belajar mahasiswa . Berikut indikator penilaian dalam penyebaran angket dapat dilihat pada table dibawah ini:

Tabel 1. Indikator Penilain dalam penyebaran angket

\begin{tabular}{|l|l|l|c|l|}
\hline No & $\begin{array}{l}\text { Aspek } \\
\text { Penilaia } \\
\text { n }\end{array}$ & $\begin{array}{l}\text { Indikat } \\
\text { or }\end{array}$ & $\begin{array}{c}\text { No } \\
\text { butir } \\
\text { soal }\end{array}$ & $\begin{array}{l}\text { Jum } \\
\text { lah }\end{array}$ \\
\hline 1 & $\begin{array}{l}\text { Dengan } \\
\text { memanfa } \\
\text { atkan } \\
\text { teknologi } \\
\text { pembelaj } \\
\text { aran } \\
\text { mampu }\end{array}$ & $\begin{array}{l}\text { Pemaha } \\
\text { man dan } \\
\text { penggun } \\
\text { aan } \\
\text { teknolog }\end{array}$ & $\begin{array}{l}1-15 \\
\text { i }\end{array}$ & $\begin{array}{l}15 \\
\text { soal }\end{array}$ \\
\\
\hline
\end{tabular}




\begin{tabular}{|c|c|c|c|c|}
\hline & $\begin{array}{l}\text { menyeles } \\
\text { aikan } \\
\text { pekerjaan } \\
\text { dan tugas } \\
\text { kuliah } \\
\text { dengan } \\
\text { cepat. }\end{array}$ & $\begin{array}{l}\text { jaran } \\
\text { (Video } \\
\text { pembela } \\
\text { jaran ) }\end{array}$ & & \\
\hline 2 & \begin{tabular}{|l} 
Penggun \\
aan \\
media \\
pembela \\
jaran \\
berbasis \\
teknolog \\
$\mathrm{i}$ \\
menarik \\
perhatia \\
$\mathrm{n}$ \\
sehingga \\
menumb \\
uhkan \\
motivasi \\
belajar .
\end{tabular} & $\begin{array}{l}\text { Motivasi } \\
\text { belajar } \\
\text { siswa }\end{array}$ & $1-15$ & $\begin{array}{l}15 \\
\text { Soal }\end{array}$ \\
\hline 3 & $\begin{array}{l}\text { Meman } \\
\text { faatkan } \\
\text { teknolo } \\
\text { gi } \\
\text { Pembel } \\
\text { ajaran } \\
\text { sehingg } \\
\text { a hasil } \\
\text { belajar } \\
\text { menda } \\
\text { pat } \\
\text { nilai } \\
\text { yang } \\
\text { memua } \\
\text { skan. }\end{array}$ & $\begin{array}{l}\text { Prestasi } \\
\text { belajar } \\
\text { siswa }\end{array}$ & $1-15$ & $\begin{array}{l}15 . S \\
\text { oal }\end{array}$ \\
\hline
\end{tabular}

Dalam interpretasi penilaian menggunakan skala likert yang skornya 15 dengan dengan jawaban setiap item instrument mempunyai gradasi dari sangat positip sampai negative.
Tabel 2. Katagori persentase

\begin{tabular}{|l|l|l|}
\hline No & Persentase & Interpretasi \\
\hline 1 & $81 \%-90 \%$ & Sangat setuju \\
\hline 2 & $61 \%-80 \%$ & Setuju \\
\hline 3 & $41 \%-60 \%$ & Ragu-ragu \\
\hline 4 & $21 \%-\$ \%$ & Tidak setuju \\
\hline 5 & $0 \%-20 \%$ & $\begin{array}{l}\text { Sangat tidak } \\
\text { setuju }\end{array}$ \\
\hline
\end{tabular}

Berdasarkan hasil kuisioner yang dibagikan kepada mahasiswa maka dapat dilihat pada gambar 1. bahwa pengetahuan mahasiswa terhadap teknologi pembelajaran sebesar $32,07 \%$, sedangkan motivasi siswa untuk penggunaan media teknologi pembelajaran sebesar $35.09 \%$, dan prestasi belajar siswa pada mata pelajaran media pengajaran sebesar 28,09 Mahasiswa menganggap bahwa penggunaan media pengajaran khususnya video sangat mendukung prestasi pembelajaran dalam perkuliahan di kelas .

Tabel : 3 Discriptif Analisis

\begin{tabular}{lccc}
\hline & \multicolumn{2}{c}{ Pengunaa } & Motiva \\
& n vedio & si & Prestasi \\
\hline Valid & 40 & 40 & 40 \\
Missing & 1 & 1 & 1 \\
Mean & 54.550 & 56.275 & 51.825 \\
Std. & 4.019 & 3.782 & 3.054 \\
Deviation & & & \\
Minimum & 43.000 & 52.000 & 45.000 \\
Maximum & 61.000 & 65.000 & 59.000 \\
\hline
\end{tabular}

Analisi diskriptif menunjukan mean dari penggunaan vedio 54.55 dengan standar deviasi 4.01, dan motivasi mahasiswa dalam mengikuti perkuliahan media pembelajaran IPS sebesar 56,27 standar deviasi 3.78 serta Mean dari prestasi mahasiswa dalam perkuliahan media pembelajaran IPS sebesar 51,82 
dengan standar deviasi 3,054. Ini menunjukan bahwa memang motivasi belajar mahasiswa dengan menggunaan media pembelajaran sangat signifikan , seperti pada table di atas. Dari grafik kita bisa melihat bahwa memang penggunaan video pembelajaran sangat disukai oleh mahasiswa, yang dapat dikatakan berdasarkan grafik berada di angka $50 \%$ lebih sedangkan motivasi dan prestasi belajar mahasiswa menunjukan hasil yang signifikan, seperti grafik dibawah ini .
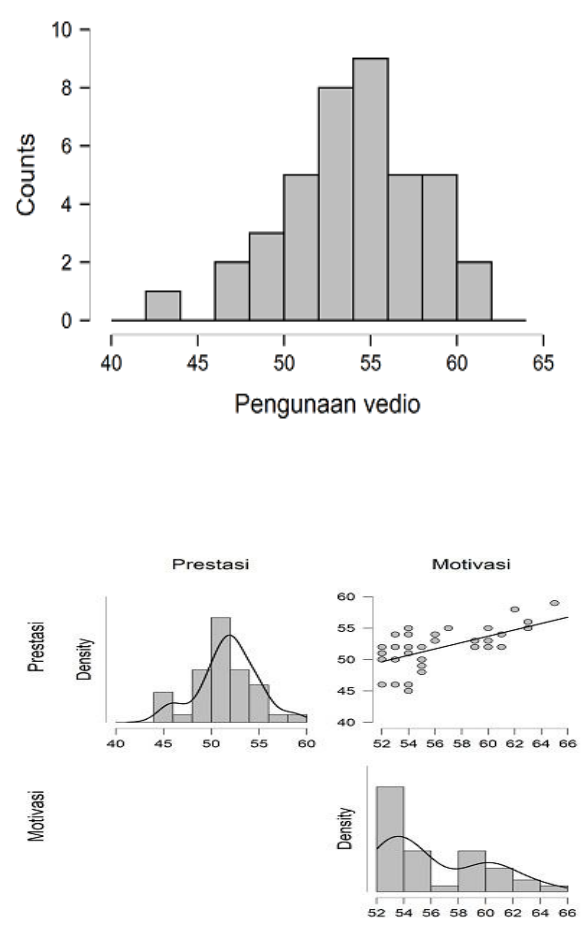

Grafik diatas menunjukan prestasi mahasiswa dalam pembelajaran lebih rendah sedikit jika dibandingkan dengan motivasi belajar mahasiswa dengan menggunaan vedio pembelajaran yang cukup signifikan.

\section{Pembahasan}

Schunk dalam Rina Cahyani dkk menjelaskan bahwa motivasi merupakan suatu proses mengarahkan motif untuk suatu tujuan tertentu yang menjadi pendorong dan pemberi arah prilaku seseorang. Motivasi merupakan unsur penting dari pembelajaran efektif yang dapat mendorong subjek belajar untuk mencapai efektivitas pengajaran yang berhasil. Seseorang akan berhasil dalam pembelajaran apabila pada dirinya ada keinginan untuk belajar, keinginan untuk belajar disebut dengan motivasi. (Rina Cahyani , Sarwono, Puguh Karyanto, 2016). ${ }^{8}$

Pada bagian ini akan diulas mengenai pengunaan media video sebagai pembelajaran, meliputi; unsur-unsur media video, manfaat video dan peran video dalam pembelajaran

1. Unsur - Unsur Media Video

a. Teks. Teks terdiri dari unit-unit bahasa dalam penggunaannya. Unit-unit bahasa tersebut adalah merupakan unit gramatikal seperti klausa atau kalimat namun tidak pula didefenisikan berdasarkan ukuran panjang kalimatnya. Teks terkadang pula digambarkan sebagai sejenis kalimat yang super yaitu sebuah unit gramatikal yang lebih panjang dari pada sebuah kalimat yang saling berhubungan satu sama lain. Jadi sebuah teks terdiri dari beberapa kalimat sehingga hal itulah yang membedakannya dengan pengertian kalimat tunggal. Selain itu sebuah teks dianggap sebagai unit semantik yaitu unit bahasa yang berhubungan dengan bentuk maknanya. Dengan demikian teks itu dalam realisasinya berhubungan dengan klausa yaitu satuan bahasa yang terdiri atas subjek dan predikat dan apabila diberi intonasi final akan

8 Rina Cahyani , Sarwono, Puguh Karyanto, Penggunaan Media Video untuk Meningkatkan Motivasi dan Hasil Belajar Materi Biosfer pada Siswa Kelas XI IPS MAN 2 Pontianak Tahun Pelajaran 2015/2016, Jurnal GeoEco ISSN: 2460-0768 Vol. 2, No.2 (Juli 2016) p. 198-207 
menjadi sebuah kalimat. (Hassan, 1976:1) ${ }^{9}$

b. Gambar (Image). Gambar dapat meringkas dan menyajikan data kompleks dengan cara yang baru dan lebih berguna. Sering dikatakan bahwa sebuah gambar mampu menyampaikan seribu kata tapi, itu hanya berlaku ketika kita bisa menampilkan gambar yang diinginkan saat kita memerlukannya. Gambar juga bisa berfungsi sebagai ikon, yang bila dipadu dengan teks, menunjukkan berbagai opsi yang bisa dipilih (select) atau gambar bisa muncul full-screen menggantikan teks, tapi tetap memiliki bagian-bagian tertentu yang berfungsi sebagai pemicu yang bila di klik akan menampilkan objek atau event multimedia lain (Suyanto,2003:261). ${ }^{10}$

c. Suara (Audio). Pengertian suara (audio) menurut Suyanto, 2003:273 ${ }^{11}$ adalah sesuatu yang disebabkan perubahan tekanan udara yang menjangkau gendang telinga manusia. Audio terdiri dari beberapa jenis yaitu Waveform Audio, Format DAT, Format MIDI, Audio CD, MP3

d. Animasi. Pemakaian animasi dalam komputer telah dimulai dengan ditemukannya software komputer yang dapat digunakan dalam berbagai keperluan seperti melakukan ilustrasi di komputer, serta membuat perubahan antara gambar satu ke gambar berikutnya sehingga dapat terbentuk satu gabungan yang utuh.

2. Manfaat Video

9 .Ruqaiya Hasan. 1976, Cohesion in english. London: Longman .p.

10 Suyanto, M. 2003. Multimedia alat untuk meningkatkan keunggulan bersaing, Jakarta .p.

${ }^{11}$ Idem.p. 273.
Manfaat media video menurut Andi Prastowo (2012 : 302), ${ }^{12}$ antara lain :

a. Memberikan pengalaman yang tak terduga kepada peserta didik,

b. Memperlihatkan secara nyata sesuatu yang pada awalnya tidak mungkin bisa dilihat,

c. Menganalisis perubahan dalam periode waktu tertentu,

d. Memberikan pengalaman kepada mahasiswauntuk merasakan suatu keadaan tertentu, dan

e. Menampilkan presentasi studi kasus tentang kehidupan sebenarnya yang dapat memicu diskusi peserta didik.

Berdasarkan penjelasan di atas, dengan video mahasiswa dapat menyaksikan suatu peristiwa yang tidak bisa disaksikan secara langsung, berbahaya, maupun peristiwa lampau yang tidak bisa dibawa langsung ke dalam kelas. Mahasiswa pun dapat memutar kembali video tersebut sesuai kebutuhan dan keperluan mereka. Pembelajaran dengan media video menumbuhkan minat serta memotivasi untuk selalu memperhatikan pelajaran.

3. Peran Video dalam Pembelajaran

Penggunaan video sebagai bahan bantu mengajar memberikan satu pengalaman baru kepada semua peserta didik. Media video dan televisi dapat membawa pelajar ke mana saja, terutama sekali jika tempat atau peristiwa yang ditayangkan itu terlalu jauh untuk dilewati, atau berbahaya.

Dengan penayangan video pembelajaran , peserta didik merasa seolah-olah mereka berada atau turut serta dalam suasana yang digambarkan. Sebagai contoh, proses penjalanan listrik dapat ditunjukkan kepada peserta didik melalui video pembelajaran .Kiranya dapat

${ }^{12}$ Andi Prastowo. (2012). Panduan Kreatif Membuat Bahan Ajar Inovatif. Yogyakarta: Diva Press. 
membantu peserta didik membayangkan proses aliran listrik yang sedang berjalan di samping memberi pengalaman kepada para peserta didik secara visual. Menurut Norizan, 2002 (dalam Norhaziana, 2005 ${ }^{13}$ ) menyatakan, sesuatu media berbentuk simulasi adalah perisian yang memberi gambaran situasi sesuatu keadaan. Pengguna akan seolah-olah berada di tempat kejadian dan boleh merespon terhadap keadaan tersebut.

Pengaruh media video pembelajaran akan lebih cepat masuk ke dalam diri manusia daripada media yang lainnya. Karena penayanggannya berupa cahaya titik fokus, sehingga dapat mempengaruhi fikiran dan emosi manusia. Dalam kegiatan belajar mengajar, fokus dan mempengaruhi emosi dan psikologi anak didik sangat diperlukan. Karena dengan hal tersebut mahasiswa akan lebih mudah memahami pelajarannya. Tentunya media video yang disampaikan kepada anak didik harus bersangkutan dengan tujuan pembelajaran.

Menurut Hamalik, 1986: 43 (dalam Azhar, 2003: 15-16) ${ }^{14}$ Pemakaian media pengajaran dalam proses belajar mengajar dapat membangkitkan keinginan dan minat yang baru, membangkitkan motivasi dan stimulan kegiatan belajar, dan bahkan membawa pengaruh psikologis terhadap peserta didik. Penggunaan media pengajaran pada tahap orientasi pengajaran akan sangat membantu keefektifan proses pembelajaran dan penyampaian pesan dan isi pelajaran pada saat itu. Pengalaman belajar yang diperoleh peserta didik dapat melalui proses perbuatan atau mengalami sendiri apa yang dipelajari, proses mengamati dan mendengarkan melalui

\footnotetext{
${ }^{13}$ Yudianto, Arif, 2017, Proseding pada seminar nasional, Penerapan Video sebagai media pembelajaran.p.236.

14 Azhar. 2003, Media Pembelajaran. Jakarta: Raja Grafindo Persada.
}

media tertentu dan mendengarkan melalui bahasa. Semakin konkret mahasiswa mempelajari bahan pengajaran, maka semakin banyak pengalaman yang diperoleh peserta didik. Sebaliknya, semakin abstrak mahasiswa memperoleh pengalaman, maka semakin sedikit pengalaman yang akan diperoleh peserta didik. Pada kelas eksperimen yang mana memanfaatkan media video sebagai media pembelajaran sebelum praktikum dilakukan, membuat kegiatan praktikum mahasiswa lebih terarah (Retno, dalam Dimyati, 2006: 9) ${ }^{15}$.

Penyampaian materi melalui media video pembelajaran dalam pembelajaran bukan hanya sekedar menyampaikan materi sesuai dengan kurikulum. Akan tetapi ada hal lain yang perlu diperhatikan yang dapat mempengaruhi minat peserta didik dalam belajar. Hal tersebut berupa pengalaman atau situasi lingkungan sekitar, kemudian dibawakan ke dalam materi pelajaran yang disampaikan melalui video . Selain itu juga dalam pelajaran peraktek peserta didik akan lebih mudah melakukan apa yang dilihatnya dalam video daripada materi yang disampaikan melalui buku atau gambar. Kegiataan seperti ini akan memudahkan peserta didik serta guru dalam proses belajar mengajar.

Ada banyak kelebihan video ketika digunakan sebagai media pembelajaran di antaranya menurut Nugent (dalam Smaldino, 2008: $310 \quad)^{16}$ video pembelajaran merupakan media yang cocok untuk berbagai ilmu pembelajaran, seperti kelas, kelompok kecil, bahkan satu mahasiswa seorang diri sekalipun. Hal itu, tidak dapat dilepaskan dari kondisi para mahasiswa saat ini yang tumbuh berkembang dalam dekapan budaya televisi, di mana paling tidak setiap 30

15 Dimyati dan Mudjiono. 2006. Belajar dan Pembelajaran. Jakarta: PT Rineka Cipta.

${ }^{16}$ Nugent, 2005. Smaldino dkk. 2008: 310. 
menit menayangkan program yang berbeda. Dari itu, video dengan durasi yang hanya beberapa menit mampu memberikan keluwesan lebih bagi dosen dan dapat mengarahkan pembelajaran secara langsung pada kebutuhan mahasiswa. Motivasi belajar merupakan suatu dorongan pada diri peserta didik untuk belajar.Motivasi ini dapat timbul dari dalam diri peserta didik (intrinsik) ataupun karena dorongan dari pihak lain di luar diri mahasiswa (ekstrinsik). Vallerands (dalam Yen, Tuan dan Liao, 2011). ${ }^{17}$ mengemukakan teori model hirarki untuk motivasi intrinsic dan ekstrinsik berdasarkan pembedaan antara motivasi pribadi dan situasi pendukung motivasi. Motivasi pribadi merupakan kecenderungan yang luas terkait aktivitas keterlibatan, baik orientasi intrinsik maupun ekstrinsik. Adapun situasi pendukung motivasi lebih menekankan pada pengalaman motivasi individu ketika peserta didik terlibat dalam aktivitas atau dengan kata lain motivasi saat ini (sesaat). Hasil penelitian Yen, Tuan dan Liao $\left(2011^{18}\right)$ menyimpulkan bahwa dalam setting pembelajaran berbasis web, kepentingan dan ketertarikan (sebagai variable situasi pendukung motivasi) lebih berperan dibandingkan motivasi intrinsik, sedangkan pada pembelajaran di kelas, motivasi intrinsic lebih berperan dalam mendukung pemahaman konsep mahasiswa $^{19}$. Hasil analisis terhadap data motivasi belajar peserta didik pada

\footnotetext{
${ }^{17}$ Yen, H.C., Tuan, H.L., dan Liao, C.H. 2011. "Investigating the influence ofMotivation on Students'Conceptual Learning Outcomes In WebBasedvs.Classroom-Based Science Teaching Contexts". Research Science Education,p.41:211224.

$$
{ }^{18} \text { Ibid,. }
$$

${ }^{19}$ Erfan Priyambodo, dkk. Pengaruh media pembelajaran intraktif berbasis web terhadap motivasi belajar mahasiswa Jurnal pendidikan, Volume 42, Nomor 2, November 2012,h. 99 - 109
}

penelitian menunjukkan bahwa motivasi awal peserta didik untuk mengikuti pembelajaran relatif tinggi. Kemudian setelah dilakukan pembelajaran dengan menggunakan media Vedio pembelajaran ternyata dapat meningkatkan skor motivasi belajar peserta didik sebesar 56,27 \%. Angket terbuka diberikan pada peserta didik untuk mendukung data skor motivasi belajar tersebut. Berdasarkan hasil analisis angket terbuka yang diberikan kepada peserta didik diketahui bahwa semua peserta didik merasa lebih termotivasi untuk mengikuti pembelajaran jika setiap pembelajaran disertai dengan penggunaan media video pembelajaran , Sejalan dengan penelitian sebelumnya, pembelajaran dalam setting web mampu meningkatkan motivasi peserta didik sebagai faktor situasi pendukung motivasi. Hal ini dapat dipahami karena pembelajaran dengan media video pembelajaran dapat digunakan sebagai perantara, yaitu meningkatkan keterlibatan peserta didik.Dalam menerapkan strategi belajar yang lebih mendalam untuk memudahkan dalam belajar konsep yang bermuara pada peningkatan hasil belajar peserta didik.

\section{E. Kesimpulan}

Dalam proses pembelajaran ada unsur penting yaitu penerapan media. Pemilihan media video pembelajaran memberikan manfaat yang besar dalam penyampaian pesan dalam pembelajaran. Media video pembelajaran merupakan media pembelajaran yang paling tepat dan akurat dalam menyampaikan pesan dan akan sangat membantu pemahaman peserta didik. Dengan adanya media video, mahasiswa akan lebih paham dengan materi yang disampaikan pendidik melalui tayangan video pembelajaran yang diputarkan. Unsur-unsur yang terdapat dalam media video seperti suara, teks, animasi, dan grafik. Dengan adanya media 
video peserta mampu mencapai kemampuan dalam ranah kognitif, afektif, psikomotorik dan meningkatkan kemampuan interpersonal.

Penggunaan media video dapat meninggkatkan motivasi belajar para peserta didik dalam mengikuti perkuliahan atau pembelajaran, menghilangkan rasa bosan dengan metode yang terapkan oleh dosen ,dengan tidak adanya variasi model dan metode pembelajaran, dengan adanya alat bantu media Video dalam pembelajaran prestasi belajar akan meningkat dan memuaskan, dan adanya Video pembelajaran dapat memotivasi peserta didik dalam proses pembelajaran serta dapat meningkatkan prestasi siswa dalam pembelajaran.

Penyampaian materi melalui media video pembelajaran dalam pembelajaran bukan hanya sekedar menyampaikan materi sesuai dengan kurikulum. Akan tetapi ada hal lain yang perlu diperhatikan yang dapat mempengaruhi minat peserta didik dalam belajar. Hal tersebut berupa pengalaman atau situasi lingkungan sekitar, kemudian dibawakan ke dalam materi pelajaran yang disampaikan melalui video . Selain itu juga dalam pelajaran peraktek peserta didik akan lebih mudah melakukan apa yang dilihatnya dalam video daripada materi yang disampaikan melalui buku atau gambar. Kegiataan seperti ini akan memudahkan peserta didik serta guru dalam proses belajar mengajar.

\section{DAFTAR PUSTAKA}

Andi Prastowo. (2012). Panduan Kreatif Membuat Bahan Ajar Inovatif. Yogyakarta: Diva Press. Arsyad,

Anitah, S. (2013). Media Pembelajaran. Surakarta : Mata Padi Presindo.

Arif Yudianto Penerapan Video seagai media pembelajaran.ISBN.978602-50088-0-1
Arikunto, S. 2011. Prosedur Penelitian Suatu Pendekatan Praktik. Jakarta: Rineka Cipta

Arsyad, A. (2013). Media Pembelajaran. Jakarta: Rajawali Press.

Azhar. 2003, Media Pembelajaran. Jakarta: Raja Grafindo Persada.

Dale H. Schunk, P. R. (2012). Motivasi dalam Pendidikan Teori, Penelitian dan Aplikasi. Jakarta Barat: Permata Puri Media.

Dimyati dan Mudjiono. 2006. Belajar dan Pembelajaran. Jakarta: PT Rineka Cipta.

Elihami, E., \& Saharuddin, A. (2017). Peran Teknologi Pembelajaran Islam dalam organisasi Belajar. Edumaspul-Jurnal Pendidikan, 1(1), 1-8.

Erfan Priyambodo, dkk. Pengaruh media pembelajaran intraktif berbasis web terhadap motivasi belajar mahasiswa. Jurnal pendidikan, Volume 42, Nomor 2, November 2012, Hal.99 - 109

Hauff, Mechthild \& Laaser, Wolfram . 1996. Educational Video and TV in Distance Education - Production and Design Aspects. (Journal of Universal Computer Science, vol. 2, no. 6 (1996), 456-473). Nugent, 2005. Smaldino dkk. 2008: 310.

Rina Cahyani, Sarwono, Puguh Karyanto, Penggunaan Media Video untuk Meningkatkan Motivasi dan Hasil Belajar Materi Biosfer pada Siswa Kelas XI IPS MAN 2 Pontianak Tahun Pelajaran 2015/2016, Jurnal GeoEco ISSN: 2460-0768 Vol. 2, No.2 (Juli 2016) Hal. 198207

Ruqaiya Hasan. 1976, Cohesion in english. London: Longman

Sadiman, A. S. (2008). Media Pendidikan. Jakarta: Raja Grafindo Persada. 
Slameto. 2003. Belajar dan Faktor-Faktor yang Mempengaruhinya. Jakarta: Rineka Cipta

Smaldino, S. E., Lowther, D. L., \& Russell, J. D. 2007.Instructional Technology and Media forLearning (9thed.).New Jersey: PearsonEducation, Inc.

Sudjana, N \& Rivai, A. 1992. Media Pembelajaran. Bandung: Penerbit CV. Sinar Baru Bandung.

Suyanto, M. 2003. Multimedia alat untuk meningkatkan keunggulan bersaing, Jakarta : Andi

Yen, H.C., Tuan, H.L., dan Liao, C.H. 2011. "Investigating the influence ofMotivation on Students'
Conceptual Learning Outcomes In Web-Basedvs.Classroom-Based

Science Teaching Contexts". Research Science Education,p.41:211-224.

Yudianto, Arif, 2017, Proseding pada seminar nasional, Penerapan Video sebagai media pembelajaran. ISBN. $\quad 978-602-50088-0-1$. Program Studi PendidikanTekenologi Informasi,Universitas Muhammadiyah Sukabumi. 
Media Video Pembelajaran Dalam Meningkatkan Motivasi Dan Prestasi Mahasiswa 